\title{
The Negative Impacts of Whale-Watching
}

\author{
E. C. M. Parsons ${ }^{1,2}$ \\ ${ }^{1}$ Department of Environmental Science and Policy, George Mason University, Fairfax, VA 22030, USA \\ ${ }^{2}$ University Marine Biological Station Millport, Great Cumbrae, Scotland KA28 OEG, UK
}

Correspondence should be addressed to E. C. M. Parsons, ecm-parsons@earthlink.net

Received 16 February 2012; Accepted 23 May 2012

Academic Editor: Lori Marino

Copyright ( 2012 E. C. M. Parsons. This is an open access article distributed under the Creative Commons Attribution License, which permits unrestricted use, distribution, and reproduction in any medium, provided the original work is properly cited.

\begin{abstract}
Whale watching is an international industry worth more than US\$2 billion globally and is currently the greatest economic activity reliant upon cetaceans. However, there is concern that whale watching is detrimental to the target species. Numerous studies have shown that cetaceans exhibit behavioral changes in response to whale-watching boat traffic. Some of these behavioral changes involve inhibiting biologically important behaviors such as feeding and resting. There is convincing evidence for some species that these can translate into population-level effects such as reduced reproductive rates. Whale watching can also cause direct mortality through collisions between vessels and animals. The introduction of guidelines or regulations for whale watching has been the most common method of trying to mitigate the impacts of boat-based whale watching. However, there is great variety in the comprehensiveness of guidelines, and even if operators have guidelines, compliance with them can be poor. Compliance might be improved if guidelines have legal under-pinnings, with monitoring and enforcement or via pressure to comply by other operators and whale-watching tourists. Simple guidelines may be more easily complied with that ones requiring specialist knowledge. Likewise undertaking simple measures, such as establishing temporal or spatial "refuges" protecting biologically important areas (e.g., feeding grounds) where whale-watching activity is prohibited, could be an appropriate mitigation strategy.
\end{abstract}

\section{Introduction}

In 2009, it was estimated that 13 million tourists took trips to see whales, dolphins, and porpoises (cetaceans) in their natural habitat, as part of an industry that generated US\$2.1 billion dollars (1.7 billion Euros) and employed 13,000 people in 119 countries $[1,2]$. As a class of tourism, it is particularly desirable as it can specifically draw tourists to a region, with many whale-watching tourists only visiting locations because of the presence of cetaceans [3-5]. It has been estimated that potentially the industry would be worth an additional US $\$ 400$ million and an additional 5,700 jobs, if maritime countries with cetacean populations, currently without whale-watching industries, were to develop them [2]. Whale watching is currently the greatest economic activity reliant upon cetaceans.

Many environmental and animal welfare groups have promoted whale watching as a tourism activity, as an alternative to the consumptive use of whales, that is, commercial whaling. Indeed, whale watching in countries that are still actively hunting whales is arguably more lucrative than whaling [5-7]. Statements from politicians in whaling countries claim that whaling and whale-watching can coexist without impacting each other (e.g., [8-12]), but data suggest that whaling can inhibit whale-watching development or potentially reduce whale watching tourism revenues within a country $[6,7,13-15]$. Whaling may even reduce tourism revenues in general, because of ethical boycotts of whaling locations by tourists [16].

Some of the fastest growing whale-watching industries are in developing countries, such as China, Cambodia, Laos, Nicaragua and Panama [1], and there is potential for considerable growth in whale-watching operations in other developing nations [2]. Seeing cetaceans as an important economic resource in developing countries may aid their conservation, with losses from directed takes (such as hunts or culling) or indirect takes (such as fisheries entanglements or boat strikes) possibly seen as removing a valuable tourism resource. In addition, it has been argued that whalewatching can provide other intangible benefits, such as being educationally beneficial, or promoting a conservation ethic in whale-watching tourists [17-19]. At present some studies suggest that these benefits are minimal [20], whilst others are more positive about the educational and public 
conservation-promoting benefits of whale watching [21-24]. It has been found that provision of education on-board whale-watching vessels increased customer satisfaction with trips [25] or was considered to be an important part of a whale-watching trip $[21,26,27]$ in several locations and this does suggest that on-board education is providing some benefits to customers.

In contrast, there is also concern that promotion of whale watching could be detrimental to the target species [28, 29], and that adverse impacts of whale watching on target species could be not only detrimental to threatened species, but also potentially "killing the goose that laid the golden egg" as far as tourism is concerned.

\section{Defining Whale Watching}

The International Whaling Commission (the recognized intergovernmental authority on the management of whales as a resource) defined whale watching as "any commercial enterprise which provides for the public to see cetaceans in their natural habitat" (page. 33 in [30]). Although the term "whale" is used, the activity refers to all cetacean species, whether they are baleen whales, or dolphins or porpoises [31]. Whale watching does not, however, include tourism activities where animals are captive in pools or sea pens [31]. In 2005, the International Whaling Commission Whale Watching Sub-committee defined various types of whalewatching activity, noting that it might not necessarily be commercial, but could include members of the public taking their personal boats out to see whales, or research trips where there are paying customers on board (which they termed "whalewatching-aided research").

It should be emphasized that although the majority of whale-watching activities are boat-based, whale watching could potentially include aerial activities (e.g., from a dirigible/airship or aircraft) or land-based whale-watching platforms. Whale-watching from land-based platforms or aerial craft such as hot air balloons is unlikely to have major impacts on cetaceans. However, powered aircraft and helicopters could produce substantial amounts of noise that could impact cetaceans, and although there has been little research into this area, it is a cause of concern (e.g., [32, 33]).

A subset of whale-watching activities involves trips where humans enter the water with wild cetaceans (i.e., "swimwith-cetacean tourism" [31]). Such activities can be "passive" where cetaceans are allowed to approach human swimmers of their own volition or "active" where the swimmers are placed in the path of oncoming cetaceans, or the cetaceans are pursued [31]. Both types of activity are more invasive than regular boat-based whale watching, especially the "active" form. Again, this is an area of particular concern of the International whaling Commission due to the potential risk to both humans and cetaceans involved in the activity [75]. Another type of tourism involving marine mammals is "provisioning" or feeding wild cetaceans-which most famously occurs in Monkey Mia in Australia. There are many concerns about the impact of this activity on the target species [76-80] as well as the risk to humans [81, 82]. However, for purposes of this paper, land-based and aerial whale watching and the impacts of wild cetacean feeding programs and swim-with-cetacean tourism are not discussed.

\section{Negative Impacts of Whale Watching}

Several studies have recorded changes in cetacean behaviour in response to whale watching. These have included changes in surfacing, acoustic, and swimming behaviour and changes in direction, group size, and coordination (Table 1).

However, it is difficult to determine the long-term negative effects (if any) of these short-term behavioural changes. Possibly they can increase an animal's energy expenditure or result in chronic levels of stress, which might have a negative effect on health [83], and it has been suggested in at least one study on bottlenose dolphins that longterm behavioural disruption may eventually lead to reduced reproductive rates [55]. Studies have shown an alteration or cessation of essential behaviours, such as feeding or resting (Table 1), and this would obviously be detrimental and could reduce fitness in the long-term, especially in situations where there is prolonged or repeated exposure. Research has also shown that boat-related sound can be drown out or "mask" cetacean vocalizations [84]. This could result in animals either being unable to communicate (which could include prevention of biologically important communication related to mating or danger) or the animals having to increase the volume of their vocalizations, which may entail an additional energetic cost [52]. The effect of noise from whale-watching traffic and its population-level impacts are issues that require more quantification and attention $[85,86]$.

Disturbance has also been linked to cetaceans temporarily or permanently abandoning areas $[68,87,88]$. In addition to the energetic costs of moving to a new location and potentially establishing a new territory, animals may be displaced to less than optimal habitats_-perhaps areas with higher predation, lower quality, or more difficulty in accessing prey species. All of these would have a cost.

However, absence of an observable reaction to whalewatching should not be interpreted as absence of an effect on cetaceans. In noncetaceans, researchers have noted that sometimes the most vulnerable animals do not react or move away from a disturbance, possibly because they lack the energy surplus to do so $[89,90]$. There are a number of reasons why cetaceans may remain within an area or continue certain behaviours despite disturbance [91]. The location may be an important source of prey or outside the area may have a high rate of predation. Animals may also lack the foraging skills to feed on different species outside of the area. These are factors that might cause animals to "tolerate" disturbance, but as noted above, the lack of an obvious reaction does not mean that the animals is not being stressed or impacted [85].

The cumulative effect of changing behaviours, displacement, or the chronic stress induced by exposure to whalewatching activity may translate into declines in health and vital rates [85]. Bejder et al. [55, 88] linked the cumulative cost of short-term behavioural changes to a decline in female reproduction, and it was this and similar studies 
TABLE 1: Examples of behavioral changes observed in cetacean species in response to whale-watching traffic.

\begin{tabular}{|c|c|c|}
\hline Behaviour change & Species & Reference \\
\hline \multirow{8}{*}{ Surfacing/diving } & Common bottlenose dolphin, Tursiops truncatus & {$[34-38]$} \\
\hline & Indo-Pacific bottlenose dolphin, Tursiops aduncus & {$[39,40]$} \\
\hline & Indo-Pacific humpback dolphin, Sousa chinensis & {$[41]$} \\
\hline & Costero, Sotalia guianensis & {$[42]$} \\
\hline & Killer whale, Orcinus orca & {$[43]$} \\
\hline & Humpback whale, Megaptera novaeangliae & {$[44]$} \\
\hline & Fin whale, Balaenoptera physalus & {$[45]$} \\
\hline & Sperm whale, Physeter macrocephalus & {$[46]$} \\
\hline \multirow{4}{*}{ "Active" behavior (e.g., tail slapping and beaching) } & Common bottlenose dolphin, Tursiops truncatus & {$[37]$} \\
\hline & Commerson's dolphin, Cephalorhynchus commersonii & {$[47]$} \\
\hline & Killer whale, Orcinus orca & {$[48]$} \\
\hline & Humpback whale, Megaptera novaeangliae & [49] \\
\hline \multirow{4}{*}{ Acoustic } & Common bottlenose dolphin, Tursiops truncatus & {$[50,51]$} \\
\hline & Killer whale, Orcinus orca & {$[52]$} \\
\hline & Humpback whale, Megaptera novaeangliae & {$[53]$} \\
\hline & Sperm whale, Physeter macrocephalus & {$[54]$} \\
\hline \multirow{2}{*}{ Group size or cohesion } & Common bottlenose dolphin, Tursiops truncatus & {$[55,56]$} \\
\hline & Costero, Sotalia guianensis & {$[42]$} \\
\hline \multirow{4}{*}{ Swimming speed } & Indo-Pacific bottlenose dolphin, Tursiops aduncus & {$[40]$} \\
\hline & Spinner dolphin, Stenella longirostris & {$[57]$} \\
\hline & Killer whale & {$[43,58]$} \\
\hline & Humpback whale, Megaptera novaeangliae & [59] \\
\hline \multirow{7}{*}{ Swimming direction } & Common bottlenose dolphin, Tursiops truncatus & {$[55,56]$} \\
\hline & Indo-Pacific bottlenose dolphin, Tursiops aduncus & {$[39]$} \\
\hline & Indo-Pacific humpback dolphin, Sousa chinensis & {$[41]$} \\
\hline & Spinner dolphin, Stenella longirostris & {$[57]$} \\
\hline & Costero, Sotalia guianensis & {$[60]$} \\
\hline & Killer whale, Orcinus orca & {$[43,58,61]$} \\
\hline & Humpback whale, Megaptera novaeangliae & {$[49,59]$} \\
\hline \multirow{9}{*}{ Altered feeding or resting } & Common bottlenose dolphin, Tursiops truncatus & {$[62-65]$} \\
\hline & Indo-Pacific bottlenose dolphin, Tursiops aduncus & {$[66]$} \\
\hline & Short-beaked common dolphin, Delphinus delphis & {$[67]$} \\
\hline & Costero, Sotalia guianensis & {$[68]$} \\
\hline & Dusky dolphin, Lagenorhynchus obscurus & {$[47,69]$} \\
\hline & Commerson's dolphin, Cephalorhynchus comersonii & {$[47]$} \\
\hline & Risso's dolphin, Grampus griseus & {$[70]$} \\
\hline & Killer whale, Orcinus orca & {$[71,72]$} \\
\hline & Humpback whale, Megaptera novaeangliae & {$[73]$} \\
\hline
\end{tabular}

that persuaded the whalewatching subcommittee of the International whaling Commission to state in 2006 that

"... there is new compelling evidence that the fitness of individual odontocetes repeatedly exposed to whale-watching vessel traffic can be compromised and that this can lead to population-level effects" (page. 54 in [92]).

In addition to altering behaviour, masking communication, or displacing animals, whale-watching tourism can also have more direct impacts. Whales have been injured or killed as a result of collisions with whale-watching vessels, especially in areas where there is a high intensity of whalewatching traffic, such as off the coast of Massachusetts or
Hawaii [92-94]. An increasing number of large, high-speed whale-watching vessels are of particular concern [75]: the speed of these vessels limits their ability, as well as that of the whales, to avoid collisions. In addition, a higher speed means greater force when collisions occur and a higher likelihood of a lethal outcome [93]. From an analysis of vessel-cetacean collisions, it was suggested that the likelihood of lethal collisions decreased when vessel speeds were below 11 knots [93]. Thus, speed restrictions may be an effective way to mitigate this problem. However, reducing speeds may impact whale-watching business profits, as a faster speed means accessing cetacean habitat more quickly, more trips being taken throughout a day, and thus more customers and revenue. 


\section{Mitigating Whale-Watching Impacts}

The introduction of guidelines or regulations has been the most common method of trying to mitigate the impacts of boat-based whale-watching. In 2004, a review and comparison of international whale watching guidelines and codes of conduct from around the world found that onethird were regulatory, that is, legal requirements and nonvoluntary, but two-thirds were entirely voluntary [95]. Most codes of conduct had regulations for minimum approach distances (e.g., 50-100 m or more), but most did not curtail especially invasive activities, for example, two-thirds had no proscriptions on feeding cetaceans and three-quarters did not prohibit touching cetaceans [95].

A study in Scotland conducted in 2000 found relatively high levels of acceptance of codes of conduct amongst operators, although it should be noted that this study found that there was a preference for operator organization or local NGO-produced guidelines, rather than guidelines produced by the national government [96]. Indeed there seemed to be resistance towards government intervention and a top-down approach in whale-watching management [96]. However, it should also be noted that a subsequent change in Scottish law led to the production of a new, governmentmandated set of marine wildlife-watching guidelines. These governmental guidelines had greater acceptance because whale-watching operators and tourism organizations were consulted extensively during the drafting of the guidelines, that is, there was a top-down remit for the production of new guidelines, but there was bottom-up involvement in their construction [97].

The existence of guidelines, regulations, or laws in an area is no guarantee of compliance with these guidelines. In Doubtful Sound in New Zealand, two-thirds of tour boat encounters with common bottlenose dolphins violated the New Zealand Marine Mammal Protection Act, with onethird of encounters involving more than one violation [98]. In Victoria, Australia, swim-with-dolphin trip operators complied with only one out of the four regulations (i.e., the number of swimmers allowed in the water with dolphins), with regulations governing time spent with animals and boat approaches frequently disregarded [99]. After this research was presented to the government and a tour operator education/awareness program was introduced, the rates of noncompliance actually increased [100]. This may have been because operators realized that despite high levels of regulatory infractions, there was little enforcement or punishment. This is arguably the crux of the matterguidelines are often poorly monitored and there is chronic lack of enforcement.

A study in New South Wales, Australia, found good levels of compliance with whale-watching guidelines [101]. Despite this, however, there were still probably impacts to cetaceans, as follows:

"The code's aim in reducing exposure of dolphins to boats was not achieved as dolphin schools were subject to consecutive approaches by numerous boats and interactions also involved boats to which the code did not apply." (page. 159 in [101]).
Therefore, although there was good compliance, a lack of broader management of whale-watching activities in the area, such as limiting vessel numbers and addressing the potential whale-watching "carrying capacity" for the region, ultimately led to a likely unsustainable situation. In several locations numbers of operators are limited by requiring licenses in order to operate, and the number of these licenses is restricted.

A factor in assessing whale-watching guideline effectiveness is that sometimes infractions are difficult to judge, especially by nonexperts. For example, it is frequently difficult to judge distances accurately at sea, especially during rough weather. If a regulation relies on an absolute approach distance, enforcement may be difficult. In addition, guidelines that mention specific behaviours (such as "feeding" or "distress" behaviours) may not be effective, as nonscientist operators could misinterpret, or simply miss, exhibited behaviours (e.g., [102]). Likewise, guidelines that have subjective values, such as "noisy activities," could be misconstrued. Guidelines with approach distances can be problematic if cetaceans actively approach a vessel-should the operator undertake avoidance manoeuvers, which could possibly be noisy and stressful for the animals? Or should the operator continue current activities despite the approaching cetaceans, as this could cause less actual disturbance to the animals?

Scarpaci et al. [100] suggested that guidelines should be simple and easily understood, be realistic/feasible in the field (considering operator expertise and local conditions), and be easily enforceable. Whilst being practical, however, simple guidelines do not necessarily cover every eventuality and unexpected problem situations may arise. Thus an ability to change and alter guidelines quickly (i.e., adaptive management) may be crucial.

Very often authorities with the responsibility to monitor whale watching lack the will, resources, or logistical support to do so (e.g., the whale-watching location might be especially remote and difficult to access). Therefore monitoring of compliance may be very poor. In some regions, enforcement may effectively come down to operator peer-pressure; that is, responsible operators may report or otherwise criticize or pressure operators who are not adhering to codes of conduct or who are not behaving responsibly (pers. obs.). Moreover, whale watching tourists may be a possible enforcement tool. A study in Scotland found that many whale-watchers engaged in environmental activities, one-half were members of environmental groups, and an astonishing one-quarter stated that they conducted voluntary work for such organisations [103]. Few other studies have looked at environmental attitudes in this tourism sector, but the high level of involvement in environmental activities suggests that whalewatching tourists could be educated as to how a sustainable whale-watching operation should be run through articles in environmental organizations' magazines and newsletters or via websites such as Planet Whale (http://www.planetwhale .com/). The environmental attitudes of the tourists could also be used to persuade operators that it is in their interest to be as environmentally-friendly and conservation-conscious as possible or they may risk alienating their customers. 
TABLE 2: A checklist of questions to ascertain whether whale watching is sustainable in a region (after [74]).

Is the marine mammal population growing?

Are marine mammals moving out of an area?

Are the marine mammals exhibiting changes in behavior?

What are the levels of biological and chemical pollutants in coastal waters?

Are marine mammal tourism operators knowledgeable about marine mammals and local culture?

Are they good education providers?

Are marine mammal operators concerned about the safety and welfare of their customers?

Does the marine mammal tourism activity aid or benefit the local community?

After reviewing many studies on the effectiveness, or lack thereof, of whale-watching guidelines, the International Whaling Commission recommended

"... that, in general, codes of conduct should be supported by appropriate legal regulations and modified if necessary as new biological information emerges" (page. 59 [32]).

One simple method for reducing the impacts of whale watching is to establish "refuges" that is, "no-go" or "sanctuary" areas. Ideally such areas would allow animals to engage in biologically important behaviours (e.g., feeding, resting, or nursing) without being disturbed by whale-watching vessels. Refuges could be spatial (e.g., a marine protected area limiting whale-watching traffic), or they could be temporal (e.g., prohibitions on whale-watching activity in a location at certain times of day, days, or seasons [104]). A clearly defined (and less subjective) spatial or temporal refuge should allow monitoring or compliance and therefore make enforcement easier for managers.

\section{Conclusions}

Whale watching can provide many socioeconomic benefits, and it also could potentially aid conservation and/or allow the public to view cetaceans as being an economically important resource alive rather than dead. However, there are many direct and indirect impacts on the target species. To be sustainable environmentally and economically, these impacts need to be minimized. In an attempt to assess whether whale watching is sustainable in an area, Hoyt [74] suggested a check list of questions to gauge the sustainability of a whale-watching industry in an area (Table 2). Many regions have accreditation schemes, where operators receive training and have to abide by certain strictures (e.g., adhering to a code of conduct or whale-watching guidelines, providing certain levels of education, using environmentallyfriendly practices), and such schemes can be beneficial if the standards for accreditation are high and the scheme is monitored, policed appropriately, and widely recognized. Along these lines, the International Whaling Commission developed a definition of "whale ecotourism," which could potentially be used as benchmark criteria for an accreditation scheme or standard for sustainable whale watching. A whale ecotourism operation is one that has taken major steps to

(i) "actively assist with the conservation of cetaceans (for example, assisting local scientists or promoting conservation initiatives),

(ii) provide accurate educational materials and/or activities about cetaceans and their associated habitats for tourists,

(iii) ...minimize their environmental impact (whether by reducing their carbon footprint, reducing the amount of waste produced by their operation or introducing other environmentally beneficial practices),

(iv) abide by a set of whale-watching regulations or an appropriate set of guidelines if no specific regulations are available for the area,

(v) provide benefits to the local host community within which the company operates. Examples of such benefits might include a company policy of preferential employment of local people, selling local handicrafts, or supporting conservation, educational, or social and cultural projects or activities in the local community." (page. 250-251 in [31]).

It is possible for whale-watching operations to minimize their impacts on cetaceans, perhaps enough so that there are no lasting or unduly negative effects. However, arguably the majority operations around the world are not doing so, to the detriment of cetacean populations internationally.

\section{Acknowledgment}

I wish to thank Naomi Rose for editorial comments on early drafts of this paper.

\section{References}

[1] S. O. O'Connor, R. Campbell, H. Cortez, and T. Knowles, Whale Watching Worldwide: Tourism Numbers, Expenditures and Expanding Economic Benefits. A Special Report from the International Fund for Animal Welfare, IFAW and Economists at Large, Yarmouth, Mass, USA, 2009.

[2] A. M. Cisneros-Montemayor, U. R. Sumaila, K. Kaschner, and D. Pauly, "The global potential for whale watching," Marine Policy, vol. 34, no. 6, pp. 1273-1278, 2010. 
[3] M. B. Orams, The Economic Benefits of Whale-Watching in Vava'u, The Kingdom of Tonga. Centre for Tourism Research, Massey University at Albany, North Shore, New Zealand, 1999.

[4] E. Hoyt, Whale Watching 2001: Worldwide Tourism Numbers, Expenditures and Expanding Socioeconomic Benefits, International Fund for Animal Welfare, Yarmouth Port, Mass, USA, 2001.

[5] E. C. M. Parsons, C. A. Warburton, A. Woods-Ballard, A. Hughes, and P. Johnston, "The value of conserving whales: the impacts of cetacean-related tourism on the economy of rural West Scotland," Aquatic Conservation, vol. 13, no. 5, pp. 397-415, 2003.

[6] J. E. S. Higham and D. Lusseau, "Urgent need for empirical research into whaling and whale watching," Conservation Biology, vol. 21, no. 2, pp. 554-558, 2007.

[7] J. E. S. Higham and D. Lusseau, "Slaughtering the goose that lays the golden egg: are whaling and whale-watching mutually exclusive?" Current Issues in Tourism, vol. 11, no. 1, pp. 63-74, 2008.

[8] International Whaling Commission, Annual Report of the International Whaling Commission, International Whaling Commission, Cambridge, UK, 2004.

[9] International Whaling Commission, Annual Report of the International Whaling Commission, International Whaling Commission, Cambridge, UK, 2005.

[10] International Whaling Commission, Annual Report of the International Whaling Commission, International Whaling Commission, Cambridge, UK, 2006.

[11] International Whaling Commission, 2007Annual Report of the International Whaling Commission, International Whaling Commission, Cambridge, UK, 2007.

[12] International Whaling Commission, Annual Report of the International Whaling Commission, International Whaling Commission, Cambridge, UK, 2008.

[13] E. C. M. Parsons and C. Rawles, "The resumption of whaling by Iceland and the potential negative impact in the Icelandic whale-watching market," Current Issues in Tourism, vol. 6, no. 5, pp. 444-448, 2003.

[14] N. Williams, "Iceland shunned over whale hunting," Current Biology, vol. 16, no. 23, pp. R975-R976, 2006.

[15] A. Endo and M. Yamao, "Policies governing the distribution of by-products from scientific and small-scale coastal whaling in Japan," Marine Policy, vol. 31, no. 2, pp. 169-181, 2007.

[16] E. C. M. Parsons and M. Draheim, "A reason not to support whaling - a tourism impact case study from the Dominican Republic," Current Issues in Tourism, vol. 12, no. 4, pp. 397403, 2009.

[17] M. Lück, "Education on marine mammal tours as agent for conservation-but do tourists want to be educated?" Ocean and Coastal Management, vol. 46, no. 9-10, pp. 943-956, 2003.

[18] J. Foxlee, "Whale watching in Hervey Bay," Parks and Leisure Australia, vol. 4, no. 3, pp. 17-18, 2001.

[19] G. Mayes, P. Dyer, and H. Richins, "Dolphin-human interaction: pro-environmental attitudes, beliefs, and intended behaviours and actions of participants in interpretation programs: a pilot study," Annals of Leisure Research, vol. 7, pp. 34-53, 2004.

[20] K. A. Stamation, D. B. Croft, P. D. Shaughnessy, K. A. Waples, and S. V. Briggs, "Educational and conservation value of whale watching," Tourism in Marine Environments, vol. 4, no. 1, pp. 41-55, 2007.
[21] G. Mayes and H. Richins, "Dolphin watch tourism: two differing examples of sustainable practices and proenvironmental outcomes," Tourism in Marine Environments, vol. 5, no. 2-3, pp. 201-214, 2008.

[22] H. Zeppei and S. Muloin, "Conservation and education benefits of interpretation on marine wildlife tours," Tourism in Marine Environments, vol. 5, no. 2-3, pp. 215-227, 2008.

[23] H. Zeppel and S. Muloin, "Conservation benefits of interpretation on marine wildlife tours," Human Dimensions of Wildlife, vol. 13, no. 4, pp. 280-294, 2008.

[24] J. B. Ambler, Whales and the people who watch them: baleen whales in Virginia's near-shore waters and the educational and conservation potential of whale watching [Doctoral thesis], George Mason University, VirginiaVa, USA, 2011.

[25] M. S. Andersen and M. L. Miller, "Onboard marine environmental education: whale watching in the San Juan islands, Washington," Tourism in Marine Environments, vol. 2, pp. 111-118, 2006.

[26] R. Ballantyne, J. Packer, and K. Hughes, “Tourists' support for conservation messages and sustainable management practices in wildlife tourism experiences," Tourism Management, vol. 30, no. 5, pp. 658-664, 2009.

[27] M. Draheim, I. Bonnelly, T. Bloom, N. Rose, and E. C. M. Parsons, "Tourist attitudes towards marine mammal tourism: an example from the dominican republic," Tourism in Marine Environments, vol. 6, no. 4, pp. 175-183, 2010.

[28] P. J. Corkeron, "Whale watching, iconography, and marine conservation," Conservation Biology, vol. 18, no. 3, pp. 847849, 2004.

[29] P. J. Corkeron, "How shall we watch whales?" in Gaining Ground: In Pursuit of Ecological Sustainability, D. M. Lavigne, Ed., pp. 161-170, International Fund for Animal Welfare, Guelph, Canada, 2006.

[30] International Whaling Commission, “Chairman's report of the forty-fifth annual meeting. Appendix 9. IWC resolution on whalewatching," Reports of the International Whaling Commission, vol. 44, pp. 33-34, 1994.

[31] E. C. M. Parsons, Fortuna, C. M. Fortuna et al., "Glossary of whalewatching terms," Journal of Cetacean Research and Management, vol. 8, supplement, pp. 249-251, 2006.

[32] International Whaling Commission, "Report of the scientific committee," Journal of Cetacean Research and Management, vol. 11, supplement, pp. 1-74, 2009.

[33] J. Luksenburg and E. C. M. Parsons, "Effects of aircraft on cetaceans: implications for aerial whalewatching," in Proceedings of the 61st Meeting of the International Whaling Commission, Madeira, Portugal, May 2009.

[34] V. M. Janik and P. M. Thompson, "Changes in surfacing patterns of bottlenose dolphins in response to boat traffic," Marine Mammal Science, vol. 12, pp. 597-602, 1996.

[35] G. D. Hastie, B. Wilson, L. H. Tufft, and P. M. Thompson, "Bottlenose dolphins increase breathing synchrony in response to boat traffic," Marine Mammal Science, vol. 19, no. 1, pp. 74-84, 2003.

[36] D. Lusseau, "Male and female bottlenose dolphins Tursiops spp. have different strategies to avoid interactions with tour boats in Doubtful Sound, New Zealand," Marine Ecology Progress Series, vol. 257, pp. 267-274, 2003.

[37] D. Lusseau, "The short-term behavioral reactions of bottlenose dolphins to interactions with boats in Doubtful Sound, New Zealand," Marine Mammal Science, vol. 22, no. 4, pp. 802-818, 2006.

[38] L. Seuront and N. Cribb, "Fractal analysis reveals pernicious stress levels related to boat presence and type in 
the IndoPacific bottlenose dolphin, Tursiops aduncus," Physica A, vol. 390, no. 12, pp. 2333-2339, 2011.

[39] E. Stensland and P. Berggren, "Behavioural changes in female Indo-Pacific bottlenose dolphins in response to boat-based tourism," Marine Ecology Progress Series, vol. 332, pp. 225234, 2007.

[40] N. Matsuda, M. Shirakihara, and K. Shirakihara, "Effects of dolphin-watching boats on the behavior of Indo-Pacific bottlenose dolphins off Amakusa-Shimoshima Island, Japan," Nippon Suisan Gakkaishi, vol. 77, no. 1, pp. 8-14, 2011 (Japanese).

[41] S. L. Ng and S. Leung, "Behavioral response of Indo-Pacific humpback dolphin (Sousa chinensis) to vessel traffic," Marine Environmental Research, vol. 56, no. 5, pp. 555-567, 2003.

[42] L. do Valle and F. C. Cunha Melo, "Behavioral alterations in the gray dolphin Sotalia guianensis (Gervais, 1953) caused by sea traffic," Biotemas, vol. 19, no. 1, pp. 75-80.

[43] R. Williams, D. E. Bain, J. C. Smith, and D. Lusseau, "Effects of vessel on behaviour patterns of individual southern resident killer whales orcinus orca," Endangered Species Research, vol. 6, no. 3, pp. 199-209, 2009.

[44] P. J. Corkeron, "Humpback whales (Megaptera novaeangliae) in Hervey Bay, Queensland: behaviour and responses to whale-watching vessels," Canadian Journal of Zoology, vol. 73, no. 7, pp. 1290-1299, 1995.

[45] G. S. Stone, S. K. Katona, A. Mainwaring, J. M. Allen, and H. D. Corbett, "Respiration and surfacing rates of fin whales (Balaenoptera physalus) observed from a lighthouse tower," Reports of the International Whaling Commission, vol. 42, pp. 739-745, 1992.

[46] J. Gordon, R. Leaper, F. G. Hartley, and O. Chappell, Effects of Whale-watching Vessels on the Surface and Underwater Acoustic Behaviour of Sperm Whales off Kaikoura, New Zealand, Science and Research Services Series No. 52, New Zealand Department of Conservation, Wellington, New Zealand, 1992.

[47] M. A. Coscarella, S. L. Dans, E. A. Crespo, and S. N. Pedraza, "Potential impact of unregulated dolphin watching activities in Patagonia," Journal of Cetacean Research \& Management, vol. 5, pp. 77-84, 2003.

[48] D. P. Noren, A. H. Johnson, D. Rehder, and A. Larson, "Close approaches by vessels elicit surface active behaviors by southern resident killer whales," Endangered Species Research, vol. 8, no. 3, pp. 179-192, 2009.

[49] K. A. Stamation, D. B. Croft, P. D. Shaughnessy, K. A. Waples, and S. V. Briggs, "Behavioral responses of humpback whales (Megaptera novaeangliae) to whale-watching vessels on the southeastern coast of Australia," Marine Mammal Science, vol. 26, no. 1, pp. 98-122, 2010.

[50] K. C. Buckstaff, "Effects of watercraft noise on the acoustic behavior of bottlenose dolphins, Tursiops truncatus, in Sarasota bay, Florida," Marine Mammal Science, vol. 20, no. 4, pp. 709-725, 2004.

[51] C. Scarpaci, S. W. Bigger, P. J. Corkeron, and D. Nugegoda, "Bottlenose dolphins, Tursiops truncatus, increase whistling in the presence of "swim-with-dolphin" tour operations," Journal of Cetacean Research and Management, vol. 2, pp. 183-185, 2000.

[52] A. D. Foote, R. W. Osborne, and A. R. Hoelzel, "Whale-call response to masking boat noise," Nature, vol. 428, no. 6986, article 910, 2004.

[53] R. S. Sousa-Lima and C. W. Clark, "Modeling the effect of boat traffic on the fluctuation of humpback whale singing activity in the Abrolhos National Marine Park, Brazil," Canadian Acoustics, vol. 36, no. 1, pp. 174-181, 2008.

[54] C. Richter, S. Dawson, and E. Slooten, "Impacts of commercial whale watching on male sperm whales at Kaikoura, New Zealand," Marine Mammal Science, vol. 22, no. 1, pp. 46-63, 2006.

[55] L. Bejder, A. Samuels, H. Whitehead, and N. Gales, "Interpreting short-term behavioural responses to disturbance within a longitudinal perspective," Animal Behaviour, vol. 72, no. 5, pp. 1149-1158, 2006.

[56] M. C. Mattson, J. A. Thomas, and D. St. Aubin, “The effect of boat activity on the behaviour of bottlenose dolphins (Tursiops truncatus) in waters surrounding Hilton Head Island, South Carolina," Aquatic Mammals, vol. 31, pp. 133140, 2005.

[57] G. Timmel, S. Courbis, H. Sargeant-Green, and H. Markowitz, "Effects of human traffic on the movement patterns of Hawaiian spinner dolphins (Stenella longirostris) in Kealakekua bay, Hawaii," Aquatic Mammals, vol. 34, no. 4, pp. 402-411, 2008.

[58] R. Williams, A. W. Trites, and D. E. Bain, "Behavioural responses of killer whales (Orcinus orca) to whale-watching boats: opportunistic observations and experimental approaches," Journal of Zoology, vol. 256, no. 2, pp. 255-270, 2002.

[59] M. Scheidat, C. Castro, J. González, and R. Williams, "Behavioural responses of humpback whales (Megaptera novaeangliae) to whalewatching boats near Isla de la Plata, Machalilla National Park, Ecuador," Journal of Cetacean Research \& Management, vol. 6, pp. 63-68, 2004.

[60] G. De Fatima Filla and E. L. De Araujo Monteiro-Filho, "Monitoring tourism schooners observing estuarine dolphins (Sotalia guianensis) in the Estuarine Complex of Cananéia, south-east Brazil," Aquatic Conservation, vol. 19, no. 7, pp. 772-778, 2009.

[61] R. Williams and E. Ashe, "Killer whale evasive tactics vary with boat number," Journal of Zoology, vol. 272, no. 4, pp. 390-397, 2007.

[62] M. C. Allen and A. J. Read, "Habitat selection of foraging bottlenose dolphins in relation to boat density near Clearwater, Florida," Marine Mammal Science, vol. 16, no. 4, pp. 815-824, 2000.

[63] D. Lusseau, "Effects of tour boats on the behavior of bottlenose dolphins: using Markov chains to model anthropogenic impacts," Conservation Biology, vol. 17, no. 6, pp. 1785-1793, 2003.

[64] R. Constantine, D. H. Brunton, and T. Dennis, "Dolphinwatching tour boats change bottlenose dolphin (Tursiops truncatus) behaviour," Biological Conservation, vol. 117, no. 3, pp. 299-307, 2004.

[65] A. Arcangeli and R. Crosti, "The short-term impact of dolphin-watching on the behaviour of bottlenose dol phins (Tursiops truncatus) in western Australia," Journal of Marine Animals and Their Ecology, vol. 2, no. 1, pp. 3-9, 2009.

[66] F. Christiansen, D. Lusseau, E. Stensland, and P. Berggren, "Effects of tourist boats on the behaviour of Indo-Pacific bottlenose dolphins off the south coast of Zanzibar," Endangered Species Research, vol. 11, no. 1, pp. 91-99, 2010.

[67] K. A. Stockin, D. Lusseau, V. Binedell, N. Wiseman, and M. B. Orams, "Tourism affects the behavioural budget of the common dolphin Delphinus sp. in the Hauraki Gulf, New Zealand," Marine Ecology Progress Series, vol. 355, pp. 287295, 2008. 
[68] M. L. Carrera, E. G. P. Favaro, and A. Souto, "The response of marine tucuxis (Sotalia fluviatilis) towards tourist boats involves avoidance behaviour and a reduction in foraging," Animal Welfare, vol. 17, no. 2, pp. 117-123, 2008.

[69] S. L. Dans, E. A. Crespo, S. N. Pedraza, M. Degrati, and G. V. Garaffo, "Dusky dolphin and tourist interaction: effect on diurnal feeding behavior," Marine Ecology Progress Series, vol. 369, pp. 287-296, 2008.

[70] F. Visser, K. L. Hartman, E. J. J. Rood et al., "Risso's dolphins alter daily resting pattern in response to whale watching at the Azores," Marine Mammal Science, vol. 27, no. 2, pp. 366-381, 2011.

[71] R. Williams, D. Lusseau, and P. S. Hammond, "Estimating relative energetic costs of human disturbance to killer whales (Orcinus orca)," Biological Conservation, vol. 133, no. 3, pp. 301-311, 2006.

[72] D. Lusseau, D. E. Bain, R. Williams, and J. C. Smith, "Vessel traffic disrupts the foraging behavior of southern resident killer whales Orcinus orca," Endangered Species Research, vol. 6, no. 3, pp. 211-221, 2009.

[73] K. A. Stamation, D. B. Croft, P. D. Shaughnessy, and K. A. Waples, "Observations of humpback whales (Megaptera novaeangliae) feeding during their southward migration along the coast of southeastern New South Wales, Australia: identification of a possible supplemental feeding ground," Aquatic Mammals, vol. 33, no. 2, pp. 165-174, 2007.

[74] E. Hoyt, "Sustainable ecotourism on Atlantic islands, with special reference to whale watching, marine protected areas and sanctuaries for cetaceans," Biology and Environment, vol. 105, no. 3, pp. 141-154, 2005.

[75] International Whaling Commission, "Report of the subcommittee on whalewatching," Journal of Cetacean Research and Management, vol. 3, supplement, pp. S297-SS307, 2003.

[76] J. Mann, R. C. Connor, L. M. Barre, and M. R. Heithaus, "Female reproductive success in bottlenose dolphins (Tursiops sp.): life history, habitat, provisioning, and group-size effects," Behavioral Ecology, vol. 11, no. 2, pp. 210-219, 2000.

[77] M. B. Orams, "Feeding wildlife as a tourism attraction: a review of issues and impacts," Tourism Management, vol. 23, no. 3, pp. 281-293, 2002.

[78] J. Mann and C. Kemps, "The effects of provisioning on maternal care in wild bottlenose dolphins, Shark Bay, Australia," in Marine Mammals: Fisheries, Tourism and Management Issues, N. Gales, M. Hindell, and R. Kirkwood, Eds., pp. 304317, CSIRO, Collingwood, Australia, 2003.

[79] D. T. Neil and B. J. Holmes, "Survival of bottlenose dolphin (Tursiops sp.) calves at a wild dolphin provisioning program, Tangalooma, Australia," Anthrozoos, vol. 21, no. 1, pp. 57-69, 2008.

[80] R. Donaldson, H. Finn, and M. Calver, "Illegal feeding increases risk of boat-strike and entanglement in Bottlenose Dolphins in Perth, Western Australia," Pacific Conservation Biology, vol. 16, no. 3, pp. 157-161, 2010.

[81] M. B. Orams, G. J. E. Hill, and A. J. Baglioni, "Pushy” behavior in a wild dolphin feeding program at Tangalooma, Australia," Marine Mammal Science, vol. 12, no. 1, pp. 107117, 1996.

[82] H. Smith, A. Samuels, and S. Bradley, "Reducing risky interactions between tourists and free-ranging dolphins (Tursiops sp.) in an artificial feeding program at Monkey Mia, Western Australia," Tourism Management, vol. 29, no. 5, pp. 994-1001, 2008.
[83] M. Orams, "Why dolphins may get ulcers: considering the impacts of cetacean-based tourism in New Zealand," Tourism in Marine Environments, vol. 1, no. 1, pp. 17-28, 2004.

[84] F. H. Jensen, M. Wahlberg, L. Bejder, and P. Madsen, "Noise levels and masking potential of small whale watching and research vessel around two delphinid species," Bioacoustics, vol. 17, pp. 166-168, 2008.

[85] A. J. Wright, N. Aguilar Soto, and A. L. Baldwin, "Do marine mammals experience stress related to anthropogenic noise?" Notarbartolo di Sciara, GInternational Journal of Comparative Psychology, vol. 20, no. 2-3, pp. 274-316, 2007.

[86] E. Martinez and M. B. Orams, "Kia angi puku to hoe I te wai: ocean noise and tourism," Tourism in Marine Environments, vol. 7, no. 3-4, pp. 191-202, 2011.

[87] D. Lusseau, "Residency pattern of bottlenose dolphins Tursiops spp. in Milford Sound, New Zealand, is related to boat traffic," Marine Ecology Progress Series, vol. 295, pp. 265-272, 2005.

[88] L. Bejder, A. Samuels, H. Whitehead et al., "Decline in relative abundance of bottlenose dolphins exposed to longterm disturbance," Conservation Biology, vol. 20, no. 6, pp. 1791-1798, 2006.

[89] J. A. Gill, K. Norris, and W. J. Sutherland, "Why behavioural responses may not reflect the population consequences of human disturbance," Biological Conservation, vol. 97, no. 2, pp. 265-268, 2001.

[90] C. M. Beale and P. Monaghan, "Behavioural responses to human disturbance: a matter of choice?" Animal Behaviour, vol. 68, no. 5, pp. 1065-1069, 2004.

[91] L. Bejder, A. Samuels, H. Whitehead, H. Finn, and S. Allen, "Impact assessment research: use and misuse of habituation, sensitisation and tolerance in describing wildlife responses to anthropogenic stimuli," Marine Ecology Progress Series, vol. 395, pp. 177-185, 2009.

[92] International Whaling Commission, "Report of the scientific committee," Journal of Cetacean Research and Management, vol. 9, supplement, pp. 1-73, 2007.

[93] D. W. Laist, A. R. Knowlton, J. G. Mead, A. S. Collet, and M. Podesta, "Collisions between ships and whales," Marine Mammal Science, vol. 17, no. 1, pp. 35-75, 2001.

[94] R. Leaper, "Summary of data on ship strikes of large cetaceans from progress reports (1996-2000)," in Proceedings of the 53rd Meeting of the International Whaling Commission, London, UK, July 2001.

[95] B. Garrod and D. A. Fennell, "An Analysis of whalewatching codes of conduct," Annals of Tourism Research, vol. 31, no. 2, pp. 334-352, 2004.

[96] E. C. M. Parsons and A. Woods-Ballard, "Acceptance of voluntary whalewatching codes of conduct in West Scotland: the effectiveness of governmental versus industry-led guidelines," Current Issues in Tourism, vol. 6, no. 2, pp. 172-182, 2003.

[97] E. C. M. Parsons, "From whaling to whale watching: a history of cetaceans in Scotland," Glasgow Naturalist. In press.

[98] D. Lusseau, "The state of the scenic cruise industry in Doubtful Sound in relation to a key natural resource: bottlenose dolphins," in Nature-Based Tourism in Peripheral Areas: Development or Disaster? M. Hall and S. Boyd, Eds., pp. 246-260, Clevedon, UK, 2004.

[99] C. Scarpaci, N. Dayanthi, and P. J. Corkeron, "Compliance with regulations by "swim-with-dolphins" operations in Port Phillip Bay, Victoria, Australia," Environmental Management, vol. 31, no. 3, pp. 342-347, 2003. 
[100] C. Scarpaci, D. Nugegoda, and P. J. Corkeron, "No detectable improvement in compliance to regulations by "swim-withdolphin" operators in Port Philip Bay, Victoria, Australia," Tourism in Marine Environments, vol. 1, pp. 41-48, 2004.

[101] S. Allen, H. Smith, K. Waples, and R. Harcourt, "The voluntary code of conduct for dolphin watching in Port Stephens, Australia: is self-regulation an effective management tool?" Journal of Cetacean Research and Management, vol. 9, no. 2, pp. 159-166, 2007.

[102] A. D. Whitt and A. J. Read, "Assessing compliance to guidelines by dolphin-watching operators in Clearwater, Florida, USA," Tourism in Marine Environments, vol. 3, no. 2, pp. 117130, 2006.

[103] C. J. G. Rawles and E. C. M. Parsons, "Environmental motivation of whale-watching tourists in Scotland," Tourism in Marine Environments, vol. 1, pp. 129-132, 2004.

[104] E. Hoyt, Marine Protected Areas for Whales, Dolphins and Porpoises: A World Handbook for Cetacean Habitat Conservation, Earthscan, London, UK, 2005. 

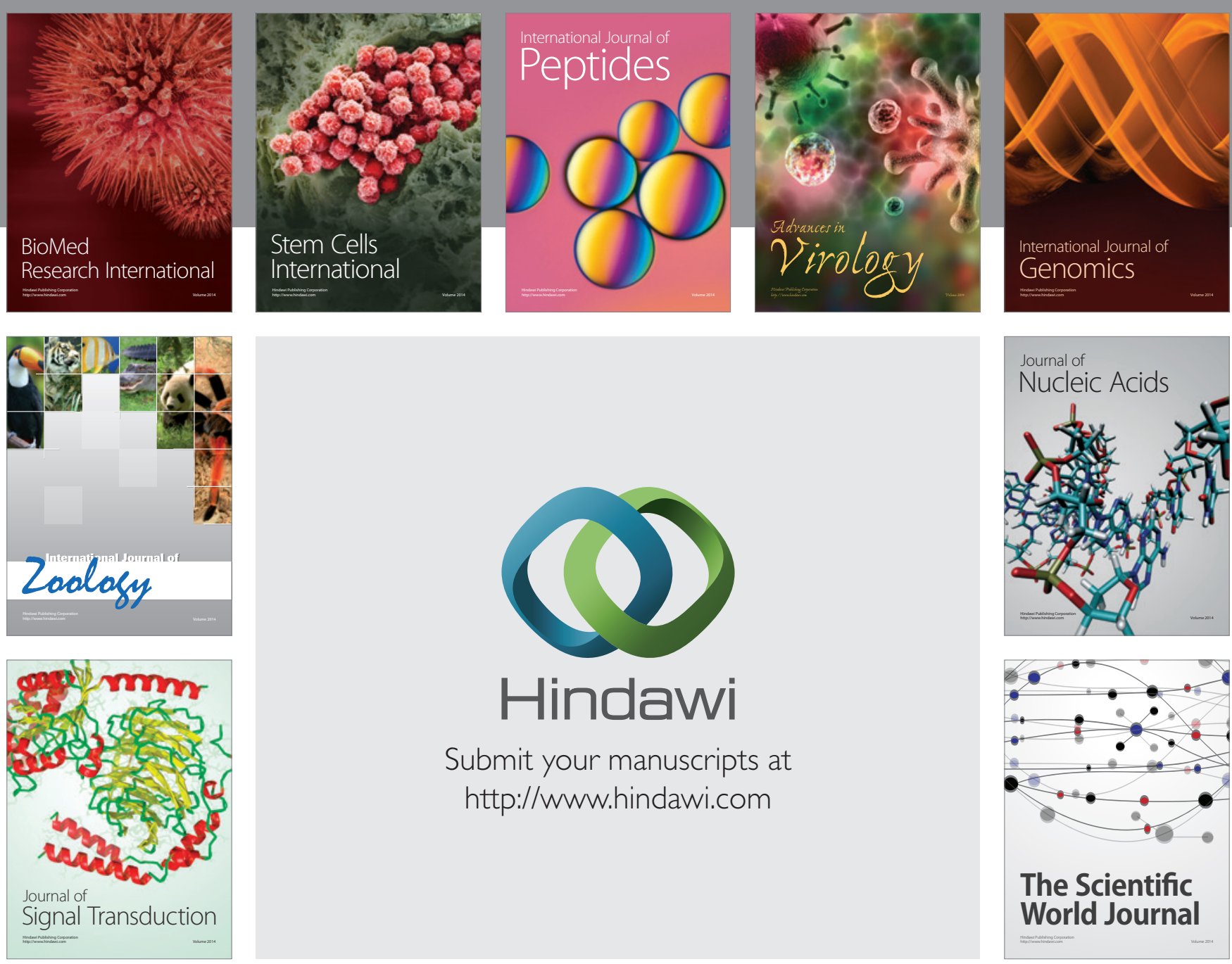

Submit your manuscripts at

http://www.hindawi.com
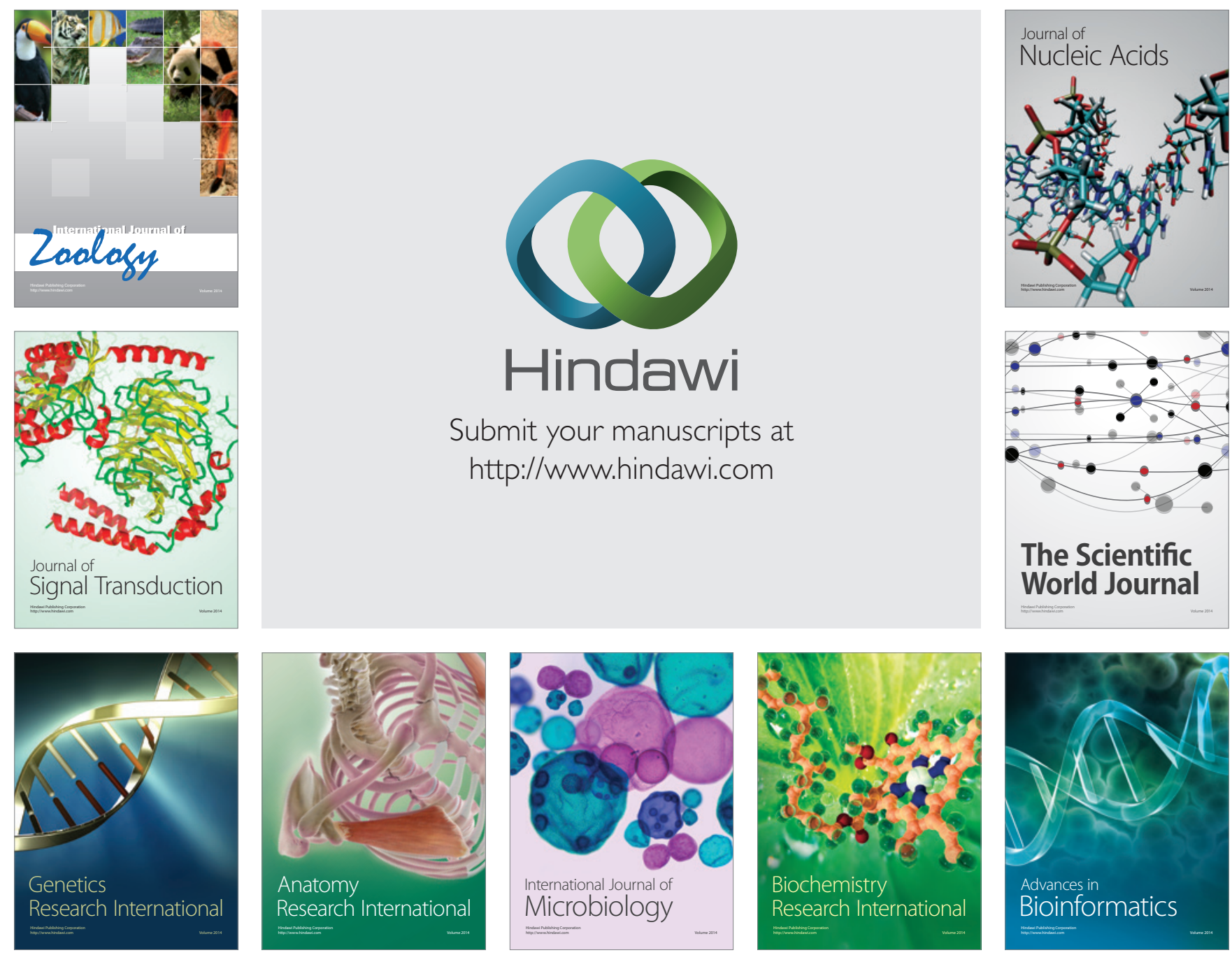

The Scientific World Journal
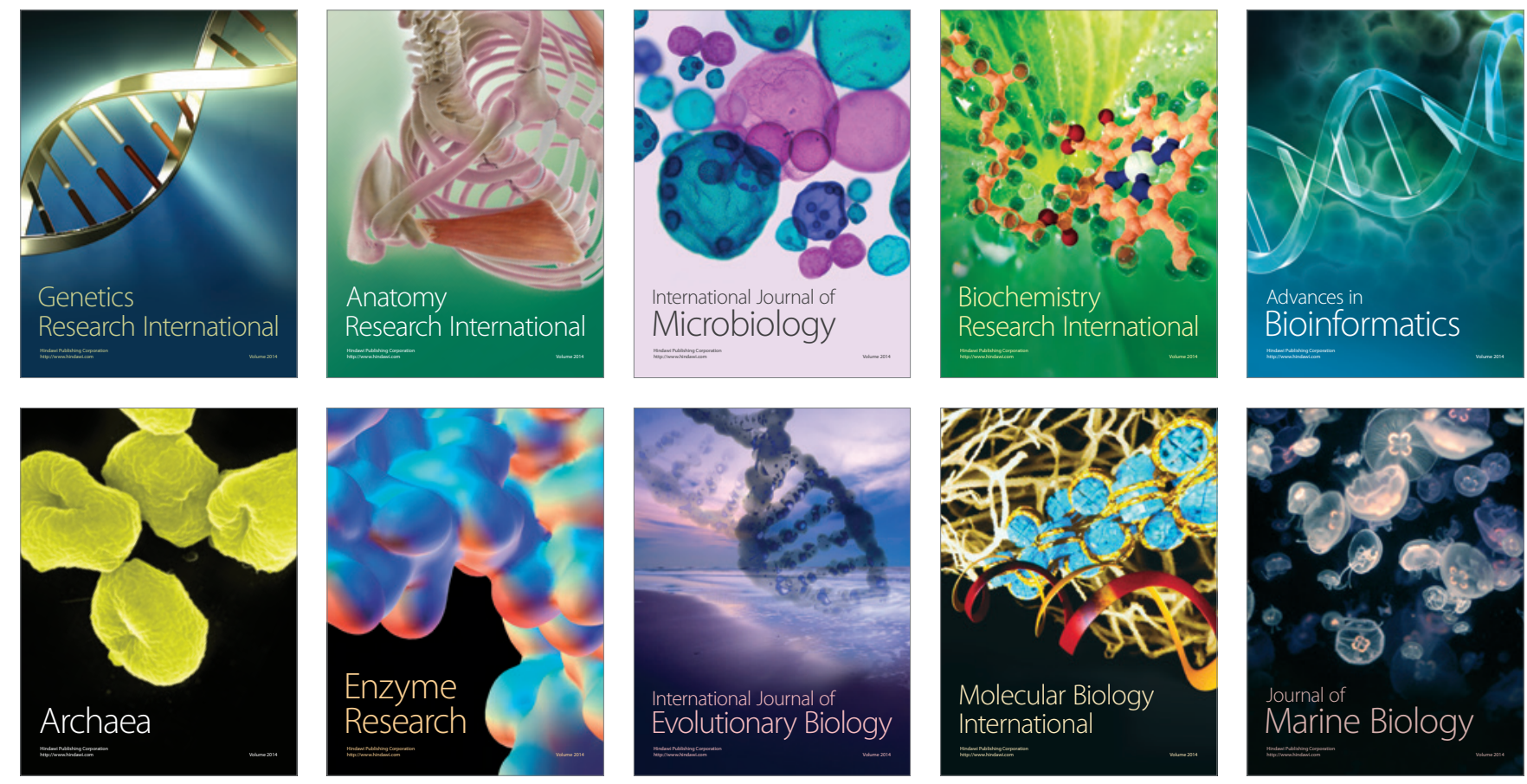